\title{
Physical Therapy Modalities and Alternative Methods in Treatment of Soft Tissue Lesions
}

\author{
Elizabeta Popova Ramova* \\ Department of Physical Therapy, \\ *Corresponding author: Elizabeta Popova Ramova, Department of Physical Therapy, Bitola, R Macedonia

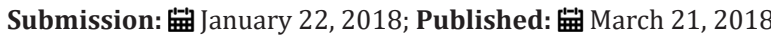

\begin{abstract}
Purpose: To present the role of physical therapy and some alternative medicine methods to improve recovery after soft tissue muscles skeletal trauma in athletes and physical active people.

Introduction: Soft tissue injuries are common in physical active people, vary from minor to major complex trauma. Soft tissue injuries include sprains, strains and bruising. Any soft-tissue injury can lead to a tenderness, swelling, haematoma, scarring, fibrosis and loss of function. In the next few days after injury, we can greatly improve recovery time by taking medicaments that decrease inflammation and speed healing. The case of treatment in PH\&Reha is soft tissue injuries of muscles skeletal system. There are onlower limb(ankle, knee, hip), the other on the shoulder (dislocations, acromioclavicular joint injuries, rotator cuff injuries), elbow and wrist.The aims of physical therapyare to relieve pain, control inflammation, hasten resolution of a haematoma, and accelerate repair, to restorate function and recovery muscle power.
\end{abstract}

Discussion: There are a variety of choices available which can provide specific and individualized results. Integration of conservative treatment and surgery with physical therapy, can decrease a time of rest and inactivity. The physical therapy has used follow physical therapy modalities: Light therapy, electro therapy, sonotherapy, hydro therapy, cold and warm applications, with proved effect. However, once the injury is stabilized, patient should take an alternative treatments for ssoft tissue injuries like acupuncture, masasage, functional taping, and herbal therapy from medicaments to greases. .

Conclusion: Modern Physical therapy can improve fast recovery and functional impairment, on science base, with physical therapy modalities and alternative medicine methods. Evaluation of effect of treatment can be with ultrasonography, and clinical test and scores.

Keywords: Soft tissue injuries; Physical therapy

\section{Introduction}

The conservative treatment of soft tissue injuries includes methods of physical therapy as the exercises according to localization and the type injury. It also includes some physical modalities, which improve the conventional methods and together with the medicament therapy they give a faster recovery of the patient [1]. A basic evaluation is made on the affected region, the ability to function on a given sport and the detection of deficits which appear. After we confirm our diagnosis we can treat the patient with some methods of physical therapy like physical therapy modalities, exercises and alternative methods, as well as passive methods like PNF and PIR [2]. Functional taping is one of useable method in early acute stage. Exercises has own effect and are by stage of condition: acute, post-acute and chronic.The well managed rehabilitation will lead to a quick recovery, achieving stability and return of the optimal sports function.

If the type of injurie requires a surgical intervention, then before and after the surgical treatmen a rehabilitation is needed and done.
This rehabilitation is used in order to maintain the current function, to prevent contractures and swelling and to reduce pain. On this rehabilitation we also add a subacute and a chronical phase of rehabilitation, which aim towards stimulation and acceleration of the regenerative process of the tissues, full spectrum of movement and maximal strength and function of the treated region [3].

In the subacute and the chronical phase of rehabilitation a team of experts is involved who are also doing an analasys and evaluation of the biomechanical and neurophysiological functions of the athlete. With a total care and evaluation for prevention od re injuring and achievement of full function of motions in total [4].

Some physical modalities are yet to be distinguished between alternative and conventional medicine, which include the photo therapy, cryotherapy, application of typing and other methods which reduce pain, swelling and stimulate the tissues [5].

Many studies refer that often the athletes are coming back on the field without fully rehabilitated injuries which is affecting 
re ocurring of the same injury, as a result of a locomotive deficit. Muscle-skeletal sonography is fast and cheap method for diagnosing and evaluating the condition of soft tissue lesions and it is a method of choice for every physician in physical therapy $[6,7]$.

\section{Discussion}

The treatment of soft tissue injuries with physical therapy requires from the physician or the PT to know all diagnostic measures for the abnormal function of the injured region [8]. During the evaluation a comparation is always needed between the injured and healthy region in terms of flexibility, stability, muscle contraction and asymmetry.

Methods of healing which are used as physical modalities are: electrotherapy $[9,10]$ heat therapy, photo therapy, sound therapy [11] and hydro gymnastics [12] which have proven effects in reduction of pain and swelling and healing of the tissue. From the alternative methods the most used is the tipping, acupuncture and herbal medicines. The exercises need to adapted to the type of injury and the affected region.

Light therapy-treatment with low level laser therapy, has a positive effect on decrease of pain and biostimulation of soft tissue repair. Polarized light are applyingafter contusion, hematomas, swelling and inflammation [13]. Treatment with ICE- has a positive effect on decrease of local pain, and swelling, and it is a method of choice in acute condition, emergency after trauma visa vi hot applications [14]. Cry co mores are useable in eminent sport clubs for increase muscles performances for sport men, without doping substances [15]. Functional typing-is easy applicable method, who decrease swelling, can immobilization area of injury and in same time decrease swelling with increase of mobility [16]. Electrical therapy - has analgesic and trophy effect with stimulation of soft tissue healing. Exercises in close and open kinetics are inseparable in modern therapy of conventional medicine, created according the type of injury, which can be acute subacute and chronical [17]. Sports massage is one of the first types of massage which is accepted by the conventional medicine. Its positive effects are a gift for every athlete and can be important in the success in the competition [18]. Herbal medicines can reduce pain without side effects and can pass doping control [19]. Hydrotherapy has an important place in quick recovery after the injury or for myorelaxing use [20]. Acupuncture is effective therapy in treatment of pain in chronic stage [21-23].

The pain is one of the reasons which can reduce the capability of the athlete. The treatment depends from the etiology of the pain and can be often treated in a conservative way. Notalways the pain requires an invasive method for treatment and if they repeat it is not rational to always be treated surgically.

\section{Conclusion}

Physical therapy like a method of treatment for soft tissue injuries special by athletes is important part of medical care, in first place because use physical therapy modalities who are not on doping control list and second it SKRATUVA short the time of recovery after trauma, with optimizing the time of inactivity and back in fool condition. In follow up of condition muscles sonography is method of choice for every physicians.

\section{Acknowledgements}

I thank for my professor mentor for muscles skeletal sonography Prof. emeritus Anastasika Poposka.

\section{References}

1. Popova Ramova E, Angelovska B (2016) Alternative medicine in sport injuries. ( $1^{\text {st }}$ edn), Bitola, Macedonia, pp. 7-9.

2. Echemendia RJ, Broglio SP, Davis GA, Guskiewicz KM, Hayden KA, et al. (2017) What tests and measures should be added to the SCAT3 and related tests to improve their reliability, sensitivity and/or specificity in sideline concussion diagnosis? A systematic review. Br J Sports Med 51(11): 895-901.

3. van Rossom S, Smith CR, Thelen DG, Vanwanseele B, Van Assche D, et al.(2018) Knee Joint Loading in Healthy Adults During Functional Exercises: Implications for Rehabilitation Guidelines. J Orthop Sports Phys Ther 6: 1-42.

4. Feddermann-Demont N1, Echemendia RJ, Schneider KJ, Solomon GS, Hayden KA, et al.(2017) What domains of clinical function should be assessed after sport-related concussion? A systematic review. $\mathrm{Br}$ J Sports Med51(11): 903-918.

5. Patel DN, Strauss EJ(2015) Alternative Therapeutic Modalities in Sports Medicine. Bull Hosp Jt Dis 73(2): 122-127.

6. Guo LJ, Cui LG, Li YM, Liao LP, Song L (2015) Use of Ultrasound in the Follow-up of Professional Athletes Receiving Conservative Treatment of Patellar Tendon Enthesiopathy. Zhongguo Yi Xue Ke Xue Yuan Xue Bao 37(5): 580-584.

7. Zhang ZJ, Ng GY, Lee WC, Fu SN (2014) Changes in morphological and elastic properties of patellar tendon in athletes with unilateral patellar tendinopathy and their relationships with pain and functional disability. PLoS One 9(10): e108337.

8. Heebner NR, Abt JP, Lovalekar M, Beals K, Sell TC, et al. (2017)Physical and Performance Characteristics Related to Unintentional Musculoskeletal Injury in Special Forces Operators: A Prospective Analysis. J Athl Train 52(12):1153-1160.

9. Nyland J, Nalon FM (2004) Therapeutic modality: Rehabilitation of the injured athlete. Clin Sport Med 23(2): 299-313.

10. Chapman BL, Liebert RB, Lininger MR, Groth JJ (2007) An introduction to physical therapy modalities. Adoles med State Art Rev 18(10): 11-13.

11. Best TM, Moore B, Jarit P, Moorman CT, Lewis GK (2015) Sustained acoustic medicine: wearable, long duration ultrasonic therapy for the treatment of tendinopathy. Phys Sportsmed 43(4): 366-374.

12. Elias GP, Varley MC, Wyckelsma VL, McKenna MJ, Minahan CL, et al. (2012) Effects of water immersion on posttraining recovery in Australian footballers. Int J Sports Physiol Perform 7(4): 357-366.

13. Thornton AL, McCarty CW, Burgess MJ (2013) Effectiveness of low-level laser therapy combined with an exercise program to reduce pain and increase function in adults with shoulder pain: a critically appraised topic. J Sport Rehabil 22(1): 72-78.

14. Knobloch K, Grasemann R, Spies M, Vogt PM (2007) Intermittent KoldBlue cryotherapy of $3 \times 10$ min changes mid-portion Achilles tendon microcirculation. Br J Sports Med 41(6): e1-e7.

15. Costello JT, Baker PR, Minett GM, Bieuzen F, Stewart IB, et al. (2015) Whole-body cryotherapy (extreme cold air exposure) for preventing and treating muscle soreness after exercise in adults. Cochrane Database Syst Rev 18(9): CD010789. 
16. Akbaş E, Atay AO, Yüksel I (2011) The effects of additional kinesio taping over exercise in the treatment of patellofemoral pain syndrome. Acta Orthop Traumatol Turc 45(5): 335-341.

17. van Rossom S, Smith CR, Thelen DG, Vanwanseele B, Van Assche D, et al (2018) Knee Joint Loading in Healthy Adults During Functional Exercises: Implications for Rehabilitation Guidelines. J Orthop Sports Phys Ther 48(3): 162-173.

18. Kargarfard M, Lam ET, Shariat A, Shaw I, Shaw BS et al. (2016) Efficacy of massage on muscle soreness, perceived recovery, physiological restoration and physical performance in male bodybuilders. J Sports Sci 34(10): 959-965.

19. Black CD, Herring MP, Hurley DJ, O’Connor PJ (2010) Ginger (Zingiber officinale) reduces muscle pain caused by eccentric exercise. J Pain 11(9): 894-903.
20. Brady B1, Redfern J, MacDougal G, Williams J (2008) The addition of aquatic therapy to rehabilitation following surgical rotator cuff repair: a feasibility study. Physiother Res Int 13(3): 153-161.

21. Speed C (2015) Acupuncture's role in tendinopathy: new possibilities. Acupunct Med 33(1): 7-8.

22. Zhang BM, Zhong LW, Xu SW, et al. (2013) Acupuncture for chronic Achilles tendnopathy: a randomized controlled study. Chin J Integr Med 19(12): 900-904.

23. Osborne NJ1, Gatt IT (2010) Management of shoulder injuries using dry needling in elite volleyball players. Acupunct Med 28(1): 42-455.
Creative Commons Attribution 4.0

International License

For possible submissions Click Here
Submit Article

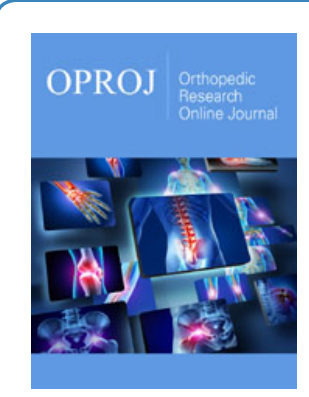

\section{Orthopedic Research Online Journal}

Benefits of Publishing with us

- High-level peer review and editorial services

- Freely accessible online immediately upon publication

- Authors retain the copyright to their work

- Licensing it under a Creative Commons license

- Visibility through different online platforms 